\title{
DEFICIT FINANCING AND ECONOMIC RECOVERY
}

\author{
Ihegboro Ifeoma Maria ${ }^{1 i}$, \\ Igwemeka Ebele Cecilia ${ }^{2}$, \\ Nnenna Georgina Nwonye ${ }^{3}$, \\ Okereke Lawrence Okoronkwo", \\ Onodugo Ifeoma ${ }^{5}$, \\ Collins Chimkamma Chinda ${ }^{6}$ \\ 1,2.3PhD, Department of Banking and Finance, \\ University of Nigeria, Enugu Campus, \\ Nigeria \\ 4,5,Department of Management, \\ University of Nigeria, Enugu Campus, \\ Nigeria \\ ${ }^{6} \mathrm{PhD}$, Department of Management, \\ University of Nigeria, Enugu Campus, \\ Nigeria
}

\begin{abstract}
:
Regardless of the vast amount of debt Nigerian government accommodate annually, the projected level of development is not realized as sizeable percentage of her citizens still lives in miserable poverty, low standard of living and soaring level of unemployment and so on. Consequently, one starts to question why the theoretical proposition seems not to be working in the Nigerian perspective. It is based on these commotions that this research work seeks to scrutinize the effect of deficit financing on recovery and development of the Nigerian economy between the periods 1981 to 2015 employing error correction model and granger causality test. Study exposes that Federal Government external debt displays a significant P-value of 0.0173 with a positive coefficient of 0.000031 signifying that $1 \%$ increase in government external debt is capable of intensifying economic recovery and development in Nigeria to the tune of 0.00003 . The details of the causality test also corroborate the report in the error correction model and thus advocate that external debt extensively adds to the development of the Nigeria economy while domestic debt and deficit budget does not give the impression to granger cause economic development in Nigeria. On this basis, study affirms that deficit financing is a crucial incentive in advancing economic development in Nigeria if effectively disbursed for the primary rationale for which it was meant for. Additionally, study thus authenticates the Keynesian theory of the existence of positive relationship between deficit financing and economic recovery. On this note, study recommends that
\end{abstract}

i Correspondence: email ifeoma.ihegboro@unn.edu.ng 
executives of the Nigerian economy should harmonize the appropriation of borrowed fund and make certain that it is well utilized towards improving the capital and production dominance of the nation as this will further boost the realization of accomplishing a sustainable level of economic development in Nigeria.

Keywords: economic recovery, deficit financing, Granger causality

JEL: H12; H50

Keywords: digital finance, digital financial services, P2P payments, mobile money, financial technology

\section{Introduction}

In ongoing time concerns have been raised by specialists over the nation's expanding obligation stock even as the Federal Government means to fund the 2021 financial plan deficit with N4.28tn new acquiring which is around 33\% of the N13.59tn spending plan (DMO, 2021). A once-over of the endorsed spending plan figures shows N3.3bn would be used on overhauling of obligation (Punch Newspaper, 2021). The country's obligation profile remained at N12.12th asof the finish of June 2015. The new figure delivered by DMO implies that in five years Nigeria's obligation has since ascended by N20.08tn (Debt Management Office, 2021). It likewise implies that inside five and 90 days the country's obligation profile rose by $165 \%$.

Deficit financing is a fundamental procedure of supporting monetary development and advancement (Ali et al., 2018). In the Keynesian assessment, it has been contended that deficit financing could be taken on to face the threat of inflationaryunemployment in the created nations when there is downturn or misery. In the post Keynesian review, it has likewise been upheld that deficit financing could be applied to a portion of the difficulties of agricultural countries, particularly that of unemployment (Ali et al., 2018). During discouragements, the Keynesian way of thinking advances the development in government consumptions even above current pay. In their view, the real reason for misery is insufficient spending by the public area when the economy experiences absence of total interest, for example, the economic crisis of the early 20s of 1929 to 1932 and most as of late, the 2008 Global Financial and Economic dissolve down. This will support the interest for useful yield and to bring down the spate of unemployment (Anyanwu and Oaikhenan, 1995; Ogboru, 2006; Iya, 2014). A few monetary quandaries are set off by deficits when it is in industriousness explicitly, deficit financing contrarily influences loan cost, speculation and financial development. Formation of cash by the utilization of deficit financing brings about an increment in the load of cash and this is equipped for prompting swelling. Pointless financial developments make an extension of imports and a constriction of products so the outer hold will in general agreement. Generous consideration has been given on the results of 
deficit financing in Nigeria due to the possibility that the presence of these results in the Nigeria economy may have educated the current reasoning that the public authority through its deficit financing has added tremendously to the nation's present monetary hardships. Among the errors confronting the Nigerian economy are; tension on equilibrium of installment, declining development and weighty obligation trouble in which we (Nigeria) had $\$ 18$ billion around $60 \%$ of the $\$ 30$ billion owed the Paris Club discounted (Debt Management Office, 2006). The dread isn't deficit accordingly, this is on the grounds that monetary deficit isn't a wrongdoing yet when it surpasses the global seat characteristic of 3\% of GDP is troubling, especially when it can't be said to additional financial exercises (Anyanwu, 1997). All administration plans should be financed be it in type of expenditure on labor and products or on obtaining of resources or through loaning to the private area. The other piece of the use which has not been financed through personal expense, person's reserve funds or homegrown acquiring should be through financial deficit.

\section{Literature Review}

With an end goal to examine the association between deficit financing and how it has added to improvement of the Nigerian economy, (Monogbe et al., 2016) exactly research the impact of deficit financing and monetary advancement in Nigeria between the periods 1981 to 2014 utilizing series of assessing apparatuses which incorporate miserly blunder adjustment component, dickey more full unit root test, drive reaction, change deterioration among others. Finding uncovers that absolute cash supply in the economy and outside obligation is positive and essentially impacts financial advancement in Nigeria consequently peddling support for the Keynesian school. Subsequently study suggests that appropriate measure such be intended to guarantee significant use of acquired asset.

Eze and Nwambeke (2015), dispatched a request on the impact of deficit financing on unemployment rate in Nigeria utilizing time series that from 1970 to 2013. Five factors were utilized during the time spent examination as intermediary for deficit financing, the yield of the vector mistake amendment model uncovers that deficit financing through outside source has a positive and huge impact in settling the Nigeria economy and subsequently could help in diminishing the degree of unemployment in the country.

Onuorah and Ogbonna (2014) analyzed deficit financing and the advancement of Nigeria economy conveying a lot of assessing apparatuses which incorporate elucidating measurements, conventional rent square trade more full unit root test, etc. All factors utilized during the time spent examination were all fixed at 1(1) and has since a long time ago run relationship. The consequence of the OLS showed that homegrown obligation and outside obligation were decidedly and fundamentally identified with financial improvement in Nigeria peddling support for the Keynesian school. On that note, they prompted that administration ought to deal with the degree of deficits to ensure that it is inside a reasonable influence. 
Utomi (2014) investigated the impact of outer obligation on the advancement of the Nigeria economy utilizing a period series date and series of assessing devices which incorporates Johansson co-mix test, unit root test among others. Outer obligation stock and outside obligation overhauling was intermediary for outer obligation trouble while genuine total national output was intermediary as financial advancement pointer. Discoveries uncover since a long time ago run unimportant relationship and a bidirectional association between outside obligation and monetary improvement in Nigeria. Stevan (2010) trying to research the financial ramifications of deficit finance model twins impact of deficit. From the model, it was accounted for that there is each inclination that there is a connection between financial plan deficit and import/export imbalance. One is relied upon to be positive as it advances total interest and animates public pay while the other is negative as it prompts swarming out of private financial backers.

Benjamin and Olanipekun (2013) investigated the relationship between financial deficit and obligation in Nigeria utilizing a blunder amendment approach granger causality in assessing the stream while time series information is sourced from the CBN measurably announcement crossing from 1970 to 2011. All factor Used during the time spent exploration were fixed at 1(1) with the exception of expansion rate that became fixed at 1(0). Joahnson co-coordination test showed a since quite a while ago run relationship between the variable utilized during the time spent examination. The consequence of the granger causality test uncovers a bi-directional stream between monetary equilibrium, public obligation just as its homegrown part while causality just runs from outside obligation to financial deficit. Subsequently, the analyst attested that homegrown obligation greatly affects financial deficit and unfamiliar obligation and in this way suggested that administration ought to decide appropriate obligation blend in determining monetary advancement in Nigeria.

Fredric and Izuchukwu (2013) utilizing granger causality test and customary least square model explored the swarming out impact of spending plan deficit on private interest in Nigeria with times series information. Five distinct factors were utilized during the time spent examination, finding uncovers that utilization of deficit as a method for financing government overabundance is fervently influencing the turn of events and endurance of the private area henceforth; they prompt that cash creation could be a substitute getting in financing government deficit in Nigeria. Akinmulegun (2014) explored deficit financing and monetary advancement in Nigeria utilizing time series information traversing from 1970 to 2010. Finding uncovers that deficit financing has an adverse consequence in advancing advancement of the Nigeria economy.

In light of the analyzed empirical literatures and with a superb focus on utilized theories, there has been series of hypothetical and exact proof invalidating each other regarding whether deficit financing invigorate monetary recuperation and advancement by the method for jamming in private financial backers or forbids financial recuperation and improvement by swarming out private financial backers. The exact works of the accompanying researchers validate the way that deficit financing has a positive 
relationship with monetary recuperation and consequently material help for the Keynesian school: Monogbe et al. (2015), Faraji and Makame (2013), Onafowora and Owoye (2006), Osuka and Achinihu (2014) among others. Then again, the underneath recorded specialists are of the view that deficit financing adversely affects monetary recuperation and improvement consequently, they are of the assessment that increment in deficit financing swarm out private financial backers. On this affirmation, they material help for the neoclassical school, Ogunmuyiwa (2011), Ayadi and Ayadi (2008), Safdari and Mehrizi (2011). In any case the broad existing writing on this topic, there is no reasonable arrangement till date in the writing with regards to whether deficit financing animate monetary recuperation and improvement or restricts, for example, observational outcome fluctuates standard country. Inferable from this recognized hole, this paper plans to add to the line of study by examining the causality stream between deficit financing and monetary recuperation and improvement in Nigeria utilizing a combination of variable to catch assorted scope of government deficit and to introduce new confirmation to extend the contention around the writing.

\section{Methodology}

This research study makes use of the Ex-post Facto Research Design also known as the Investigative econometric research design as it carries out the evaluation of a data-set and looks for possible relationships among variables, due to unknown direction and strength of the relation. The data were sourced and obtained from existing documents and materials (Secondary data). These consist of the Central Bank of Nigeria (CBN) statistical Bulletin, CBN Annual Report and Statement of Account, World Bank data base, index mundi, CBN Bullion, Debt Management Office (DMO) site, text books, journals, internet sources, and lecturer's notes relating to the research work among others. The study population comprises all economic variables connected with deficit financing and economic recovery in which a series of variables were selected which include domestic debt, external debt and government deficit budget while human development index was selected as a proxy for economic recovery amid other variables between the periods 1981 $-2015$.

The model follows the classical linear regression model assumption (CLRM) in line with the models of Monogbe et al. (2015) and Isah (2012) I formulate my model in a functional form thus;

$\mathrm{HDI}=\mathrm{f}(\mathrm{FGDF})$

Where:

HDI = Human development index

FGDF $=$ Federal Government Deficit financing 
Following the theoretical inference and the foundation of the Keynesian theory, the below listed explanatory variables were applied as indicators of deficit financing while human development index is used as a proxy of economic recovery accordingly.

HDIt $=\mathrm{f}($ FGDBt, FGXDt, FGDDt)

We convert the above model into econometrics form by introducing constant term $(\alpha 0)$ and error term $(\mu)$ :

HDIt $=\alpha 0+\alpha 1$ FGDBt $+\alpha 2$ FGXDt $+\alpha 3$ FGDDt $+\mu \mathrm{t}--(3.3 a)$

Based on theories and empirical studies, I expect the explanatory variables to have a direct relationship with the explained variable which is therefore mathematically states as: A priori expectation $\alpha 1, \alpha 2, \alpha 3>0$ for equation ' $a$ '.

The above shows a positive relationship and movement of explanatory variables such as deficit budget, external debt, and domestic debt to human development index.

Where:

HDI = Human Development Index

FGDB $=$ Federal Government Deficit Budget

FGXD = Federal Government External Debt

FGDD $=$ Federal Government Domestic Debt

$\alpha 0=$ Constant Term

$\alpha 1-\alpha 3=$ Coefficients of Predictors

\section{Results and Discussion}

Following the postulation of Porter and Gujarati (2009) that time series data are prone to stationarity problems, we subject our data to stationarity test using Augmented Dickey Fuller unit root test thus.

Table 4.1: Unit Root Test Result

\begin{tabular}{|l|c|c|c|c|}
\hline Variables & ADF Stat & Critical @5\% & P-Value & Remarks \\
\hline $\mathrm{D}($ HDI $)$ & -7.26448 & -2.95402 & 0.0001 & Stationary \\
\hline $\mathrm{D}($ FGDB $)$ & -5.11582 & -2.95402 & 0.0002 & Stationary \\
\hline $\mathrm{D}($ FGDD $)$ & -4.40948 & -2.95402 & 0.0014 & Stationary \\
\hline $\mathrm{D}($ FGXD) & -3.61159 & -2.954021 & 0.0109 & Stationary \\
\hline
\end{tabular}

Source: Extraction from E-view 9 output

From the result presented in table 4.1 above, time series under investigation report stationarity at order 1(1) justifying the uniformity of the data set and thus suggest that 
we can proceed to test for long run synchronization which might have exist amongst employed variable using Johansen co-integration test.

Table 4.2: Result of Johansen Co-Integration Test

\begin{tabular}{|l|c|c|c|c|}
\hline Hypothesized & Eigenvalue & Trace Statistic & $\mathbf{0 . 0 5}$ Critical Value & Prob. $^{* *}$ \\
\hline None $^{*}$ & 0.739441 & 77.43915 & 47.85613 & 0.0000 \\
\hline At most $1^{*}$ & 0.463994 & 33.05658 & 29.79707 & 0.0203 \\
\hline At most 2 & 0.242402 & 12.47745 & 15.49471 & 0.1354 \\
\hline At most 3 & 0.095617 & 3.316563 & 3.841466 & 0.0686 \\
\hline
\end{tabular}

Source: Extraction from E-views 9 output.

Notes: Trace test indicates 2 cointegrating eqn(s) at the 0.05 level.

* denotes rejection of the hypothesis at the 0.05 level.

The report presented above captures the estimation model and thus suggests the existence of at least two co-integrating equations. This equally suggests the existence of long run association among employed variables. To this extent, having justified the existence of long run association among employed variable, I proceed in my analysis by introducing restricted VAR estimated which is Vector Auto regression mechanism (VECM). The condition for introducing this estimation tool is prior to presence of cointegrating equation among employed variables.

Table 4.3: Result of the Error Correction Model

\begin{tabular}{|c|c|c|c|c|}
\hline \multicolumn{5}{|c|}{ Dependent Variable: HDI } \\
\hline \multicolumn{5}{|l|}{ Method: Least Squares } \\
\hline \multicolumn{5}{|c|}{ Date: 06/12/21 Time: $15: 27$} \\
\hline \multicolumn{5}{|c|}{ Sample (adjusted): 19822015} \\
\hline \multicolumn{5}{|c|}{ Included observations: 34 after adjustments } \\
\hline Variable & Coefficient & Std. Error & $\mathrm{t}$-Statistic & Prob. \\
\hline $\mathrm{C}$ & 0.516242 & 0.009502 & 54.33066 & 0.0000 \\
\hline FGDB & $2.86 \mathrm{E}-05$ & $3.66 \mathrm{E}-05$ & 0.782666 & 0.4402 \\
\hline FGDD & $-2.96 \mathrm{E}-06$ & $1.46 \mathrm{E}-05$ & -0.202383 & 0.8410 \\
\hline FGXD & $1.31 \mathrm{E}-05$ & $5.20 \mathrm{E}-06$ & 2.525171 & 0.0173 \\
\hline $\mathrm{ECM}(-1)$ & -0.729070 & 0.146785 & -4.966920 & 0.0000 \\
\hline R-squared & 0.721057 & \multicolumn{2}{|c|}{ Mean dependent var } & 0.520294 \\
\hline Adjusted R-squared & 0.668789 & \multicolumn{2}{|c|}{ S.D. dependent var } & 0.058852 \\
\hline S.E of regression & 0.038646 & \multicolumn{2}{|c|}{ Akaike info criterion } & -3.533691 \\
\hline Sum squared residual & 0.043312 & \multicolumn{2}{|c|}{ Schwarz criterion } & -3.309226 \\
\hline Log likelihood & 65.07274 & \multicolumn{2}{|c|}{ Hannan-Quinn criter. } & -3.457142 \\
\hline F-statistic & 11.88218 & \multicolumn{2}{|c|}{ Durbin-Watson stat } & 2.511539 \\
\hline Prob(F-statistic) & 0.000008 & & & \\
\hline
\end{tabular}

Source: Extraction from E-view 9 output.

Error correction mechanism is introduced in fulfillment of the existence of co-integrating equation as established by the result of the Johansen reported in table 2 above. Secondly, in order to ascertain the speed at which disequilibrium in the explained variable is corrected in the long run, error correction model was inculcated. 
Ihegboro Ifeoma Maria, Igwemeka Ebele Cecilia, Nnenna Georgina Nwonye,

Okereke Lawrence Okoronkwo, Onodugo Ifeoma, Collins Chimkamma Chinda DEFICIT FINANCING AND ECONOMIC RECOVERY

Table 4.4: Granger Causality Test Result

\begin{tabular}{|l|l|l|l|}
\hline Pairwise Granger Causality Tests & & & \\
\hline Date: 06/12/21 Time: $17: 49$ & & & \\
\hline Sample: 19812015 & & & \\
\hline Lags: 2 & & & \\
\hline Null Hypothesis: & Obs & F-Statistic & Prob. \\
\hline FGDB does not Granger Cause HDI & 33 & 0.09457 & 0.9101 \\
\hline HDI does not Granger Cause FGDB & & 0.71991 & 0.4956 \\
\hline FGDD does not Granger Cause HDI & 33 & 0.58467 & 0.5639 \\
\hline HDI does not Granger Cause FGDD & & 0.14822 & 0.8629 \\
\hline FGXD does not Granger Cause HDI & 33 & 3.2756 & 0.0427 \\
\hline HDI does not Granger Cause FGXD & & 0.1763 & 0.8393 \\
\hline
\end{tabular}

Source: Extraction from E-view 9.

The result of the pairwise causality test is judged by the probability value against the preferred level of significances (5\%). From the table presented above, there exist a causal association between federal government external debt and economic development in Nigeria with causality flowing from FGXD to HDI accordingly. This implies that FGXD granger cause HDI. This further shows the existence of supply leading relationship between external debt and human development index in Nigeria.

From the global statistics, the Adjusted R2 stood at 0.66878 which suggest that about $57 \%$ variation in the explained variable is accounted for by the explanatory variables while the error term takes care of the remaining 43 as the case may be. The Fstatistics display a coefficient of (11.88218) with a corresponding P-value of 0.00008 thus ascertaining the overall fitness of the model and therefore justifies the significances of federal government external debt of all the explanatory variables under investigation considering its P-value which is lower than the 5\% alpha value accordingly. The Durbin Watson statistic maintains a coefficient of 2.5115 showing height of acceptability and absence of auto correlation. This implies that the report from this investigation is reliable and as such could be used for decision making.

From the relative statistics, the ECM coefficient is negative and significant as expected. Error correction term shows a negative coefficient of -0.72907 and a significant P-value of 0.0000 suggesting that about $73 \%$ disequilibrium in the explained variable is corrected in the long run. The coefficient (C) displays a significant P-value of 0.0000 and a positive coefficient of 0.516242 which suggest that if all employed variables are held constant, human development index in Nigerian will increase to the tune of 0.5162 unit all things been equal. Emphatically, the result further shows that from all the three explanatory variables under investigation, only one passes the test of hypothesis. Federal government external debt exhibits a significant P-value of 0.0173 with a positive coefficient of 0.000031 suggesting that $1 \%$ increase in Federal government external debt is capable of stimulating economic development in Nigeria to the tune of 0.00003 .

Theoretically, the report from this investigation justifies the Keynesian postulation of deficit financing been a key stimulus to economic development. Practically speaking, Nigerian economy has not enjoyed the dividend of deficit financing as larger percentage 
of her citizens still lives in abject poverty, poor standard of living, high inflationary pressure, poor health facility and massive economic instability as the case may be. The question then arose that why the inverse relationship between the empirical report and practical experience? Historically, Nigerian economy has been undergoing series of economic development stages overtime but inequalities in income distribution has widened the gap between the few rich and the much poor and has such, this makes the projected development a mirage. The report from this investigation validates empirical findings of Monogbe, et al. (2015), Onuorah and Ogbonna (2014). Meanwhile, domestic debt exhibits a negative association to economic development while budget deficit report a positive but insignificant relationship to economic development in Nigeria.

\section{Conclusion and Recommendations}

Apparently, out of the ordinary, of all the explanatory variables under investigation, only one passes the test of hypothesis. Federal government external debt reveals a significant P-value of 0.0173 with a positive coefficient of 0.000031 suggesting that $1 \%$ increase in government external debt is capable of stimulating economic recovery and hence development in Nigeria to the tune of 0.00003 . The report of the causality test also confirms the result in the error correction model and thus proposes that external debt appreciably contributes to the development of the Nigeria economy while FGDD and FGDB do not appear to granger cause economic development in Nigeria.

In theory, the details from this inquiry substantiate the Keynesian postulation of deficit financing being a crucial incentive to economic development. Objectively, Nigerian economy has not benefitted from the dividend of deficit financing as larger percentage of her citizens still lives in horrible poverty, pitiable living standard, high inflationary pressure, substandard health facility and massive economic instability as the case may be. The question then arose that why the inverse relationship between the empirical report and practical experience? In recent times, Nigerian economy has been going through series of economic development stages overtime but the inequalities in income distribution have widened the gap between the few rich and the much poor and has such makes the anticipated development a fantasy. Again, financial indiscipline, moral hazard and misappropriation of fund have been documented as some of the obstructions standing against the predictable level of development in the Nigerian context. Having ascertained the following inadequacies, this research work concludes that deficit financing is a crucial incentive in advancing economic development in Nigeria if effectively disbursed for the primary rationale for which it was meant for. Additionally, study thus corroborates the Keynesian theory of the existence of positive relationship between deficit financing and economic development.

The study recommends that administrators of the Nigerian economy should harmonize the appropriation of borrowed fund and make certain that it is well utilized towards improving the capital and production dominance of the nation as this will 
further boost the realization of accomplishing a sustainable level of economic development in Nigeria.

\section{Conflict of Interest Statement}

The authors declare no conflicts of interests.

\section{About the Author}

The Author is a lecturer with a Doctor of Philosophy (PhD) in Banking and Finance at the department of Banking and Finance, University of Nigeria, Enugu Campus. Her research interest is on Theoretical and Empirical research.

\section{References}

Akinmulegun, S. O. (2014). Deficit Financing and Economic Growth in Nigeria: A Preliminary Investigation. Department of Banking and Finance, Adekunle Ajasin University, P.M.B. 001, Akungba Akoko, Ondo State, Nigeria

Ali M. B., and Ibrahim M. A. (2018). Impact of Deficit Financing on Economic Growth in Nigeria. Global Journal of Management and Business Research: B Economics and Commerce. Volume 18 Issue 3 Version 1.0 Online ISSN: 2249-4588 \& Print ISSN: 0975-5853

Ali S. A. (2014). The Impact of Public Expenditures on Economic Growth in Jordan. International Journal of Economics and Finance, 6(10), 157-167.

Anyanwu, J. C. (1997). Nigerian Public Finance: Onitsha Joanne Educational Publishers Ltd.

Anyanwu, J. C., \& Oaikhenan, H. E. (1995). Modern Macroeconomics Theory and Application in Nigeria: Journal Educational Publisher Onitsha.

Ayadi, F. S., \& Ayadi, F. O. (2008). Impact of external debt on economic growth: A comparative study of Nigeria and south Africa Journal of Sustainable Development in Africa 10(3)

Bakare I. A. O., Adesanya O. A. and Bolarinwa S. A. (2014). Empirical Investigation between Budget Deficit, Inflation and Money Supply in Nigeria. European Journal of Business and Social Sciences, 2(12), 120-134.

Benjamin, A. F., \& Olanipekun, E. F. (2013). Relationship between Fiscal Deficit and Public Debt in Nigeria: an Error Correction Approach: Journal of Economics and Behavioral Studies. 5(6) 346-355, (ISSN: 2220-6140)

Central Bank of Nigeria CBN (2012). Statistical Bulletin, Abuja: Central Bank of Nigeria. Domestic Debt Management Office (2006). Fiscal Adjustment in Nigeria: The Problem of Fiscal Dominance in Nigeria, CBN Bullion, 27 (2), April-June, 2003.

Debt Management Office Nigeria (2021). Press Release: Public Debt as at December 31, 2020. www.dmo.gov.ng 
Eric E. (2020). Guide to Economic Recovery. www.investopedia.com

Eze, O., \& Nwambeke, G. (2015). Effect of deficit financing on unemployment rate in Nigeria: International Journal of Small Business and Entrepreneurship Research $3(7), 28-46$

Faraji, K., \& Makame, S. (2013). Impact of External Debt on Economic Growth: A Case Study of Tanzania. Advances in Management and Applied Economics. 3(4), 59-82.

Fredric, O., \& Izuchukwu (2013). The Crowding out Effect of Budget Deficits on Private Investment in Nigeria. Retrieved from https://www.researchgate.net/publication/347974092 THE CROWDING OUT E FFECT OF BUDGET DEFICITS ON PRIVATE INVESTMENT IN NIGERIA

Isah, I. (2012). Deficit financing and its implication on private sector investment: the Nigerian experience: Arabian Journal of Business and Management Review (OMAN Chapter) 1(10); May

Iya, I. B., Aminu, U., \& Gabdo, A. Y. (2014). Empirical Analysis of the Effects of Fiscal Deficits on Economic Growth in Nigeria. International Journal of Emerging Technology and Advanced Engineering. Website: www.ijetae.com. 4(8), August 2014.

Keynes J. M. (1936). The General Theory of Employment, Interest and Money. London and New York: Macmillan.

Monogbe, T. G. (2016). Intergenerational causality effect of external debt on performance of the Nigeria economy (revised version): IIARD International Journal of Banking and Finance Research ISSN 2406-8634. 2(1) www.iiardonline.org

Monogbe, T. G, Dornubari I. G., \& Emah D. S. (2015). Deficit finance and the Nigeria economic performance: International Journal of Advanced Academic Research I Social Sciences and Education 1(3) (December)

Muhammad K. T., Sofia A., Syed H. Z., and Abbas, K. (2014). Effect of Budget on Trade Deficit in Pakistan: A Time Series Analysis. Journal of Finance and Economics, 2(5), 145-148.

Ogboru, I. (2006). Macroeconomics. Kaduna Liberty Publications limited.

Ogunmuyiwa, M. S. (2011). Does External Debt Promote Economic Growth? Current Research Journal of Economic Theory. 3(1), 29-35

Ojong C. M., and Hycent O. O. (2013). Effect of Budget Deficit Financing on the Development of the Nigerian Economy. European Journal of Business and Management, 5(3), (2013), 61-84.

Okelo S. O., Momanyi G., Lucas O., and Alia O. F. (2013). The Relationship between Fiscal Deficits and Economic Growth in Kenya: An Empirical Investigation. Greener Journal of Social Sciences, 3(6), 306-323.Research, 2(1), 49-54.

Okoro A. S. (2013). Deficit Financing and Trade Balance in Nigeria. International Journal of Accounting, retrieved from http://arabianjbmr.com/pdfs/AC VOL 1 2/5.pdf

Onafowora, O. A., \& Owoye, O. (2006). An Empirical Investigation of Budget and Trade Deficits: The Case of Nigeria, The Journal of Developing Areas 39(2), 153-174. 
Onuorah A. and Ogbonna G. (2014). Deficit financing and the growth of Nigeria economy: International Journal of Management Sciences and Business Research, $3(2)$

Osuka, B. O., \& Achinihu, J. O. (2014) impact of budget deficits on macro-economic variables in the Nigeria economy (1981-2012): International Journal for Innovation Education and Research. 2(11), 2014.

Penpoin.com (2021). Economic Recovery: Meaning, Types and Characteristics. Retrieved from https://penpoin.com/economic-recovery/

Safdari, M. and Mehrizi, M. A. (2011). External Debt and Economic Growth in Iran. Journal of Economic and International Finance. 3(5)

Singh J. (2021). 3 Types of budget Deficits and their Measures. Micro Economics. www.economicsdiscussion.net

Smriti J. E. (2010). Economic of the Public Sector: Third Edition. New York and London; W.W. Norton and Company, (2010), 790.

Stevan, G. (2010). Economic Implications from Deficit Finance. Department of Finance, Goce Delcev University, Stip, Macedonia. Entrepreneurship and Local Economic Development in Albania, Kosovo and Macedonia

Stiglitz J. E (2005). Fair Trade for all: How Trade can Promote Development, International Journal of Business, (2005), 23: 54

Usher A. (1998). Public Expenditure and Economic Growth in Nigeria. Department of Economics, University of llorin, Unilorin, Nigeria, 1998. 
Ihegboro Ifeoma Maria, Igwemeka Ebele Cecilia, Nnenna Georgina Nwonye,

Creative Commons licensing terms

Authors will retain copyright to their published articles agreeing that a Creative Commons Attribution 4.0 International License (CC BY 4.0) terms will be applied to their work. Under the terms of this license, no permission is required from the author(s) or publisher for members of the community to copy, distribute, transmit or adapt the article content, providing a proper, prominent and unambiguous attribution to the authors in a manner that makes clear that the materials are being reused under permission of a Creative Commons License. Views, opinions and conclusions expressed in this research article are views, opinions and conclusions of the author(s). Open Access Publishing Group and European Journal of Economic and Financial Research shall not be responsible or answerable for any loss, damage or liability caused in relation to/arising out of conflict of interests, copyright violations and inappropriate or inaccurate use of any kind content related or integrated on the research work. All the published works are meeting the Open Access Publishing requirements and can be freely accessed, shared, modified, distributed and used in educational, commercial and non-commercial purposes under a Creative Commons Attribution 4.0 International License (CC BY 4.0). 